\title{
Article
}

\section{Re-imagining management education in post-WWII Britain: Views from government and business}

\author{
Larson, Mitchell J.
}

Available at http://clok.uclan.ac.uk/31575/

Larson, Mitchell J. ORCID: 0000-0002-5506-0815 (2020) Re-imagining management education in post-WWII Britain: Views from government and business. Management \& Organizational History, 15 (2). pp. 169-191. ISSN $1744-9359$

It is advisable to refer to the publisher's version if you intend to cite from the work. http://dx.doi.org/10.1080/17449359.2020.1746346

For more information about UCLan's research in this area go to http://www.uclan.ac.uk/researchgroups/ and search for <name of research Group>.

For information about Research generally at UCLan please go to http://www.uclan.ac.uk/research/

All outputs in CLoK are protected by Intellectual Property Rights law, including Copyright law. Copyright, IPR and Moral Rights for the works on this site are retained by the individual authors and/or other copyright owners. Terms and conditions for use of this material are defined in the policies page.

\section{CLoK}

Central Lancashire online Knowledge www.clok.uclan.ac.uk

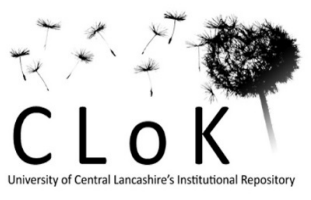




\section{Re-imagining management education in post-WWII Britain: Views from government and business}

\section{Mitchell J. Larson*}

* Lancashire School of Business \& Enterprise, Greenbank Building, University of Central Lancashire, Preston, United Kingdom, PR1 2HE mjlarson@uclan.ac.uk, +44 (0)1772 894685

This paper explores the role of government and business in establishing two business schools in Britain in the 1960s. Partly in response to the Robbins Report of 1963, business leaders and politicians re-imagined management education and formed a new type of management education institution to operate alongside and ultimately compete a variety of other methods of management preparation. These two groups collaborated to create the London Graduate School of Business and Manchester Business School as national centers of excellence for management education. Using both archival and published sources, the paper's contribution is to analyze perspectives expressed by businesspeople and political advocates involved with the business school project. It concludes that these advocates sought to create a body of educated, productive, yet socially-minded managers to lead Britain forward into the next phase of its economic development.

Keywords: management education, United Kingdom, business schools, managers 


\section{Introduction}

In autumn 1963, the Government of the United Kingdom (UK) published the report of the Committee on Higher Education. The report came to be more popularly named after the Committee's chairman, Labour peer and academic economist Lord Lionel Robbins. Enjoying wide political acceptance, the 'Robbins Report' transformed the landscape of higher education in Britain during the subsequent twenty years and arguably made its biggest mark with the establishment of the 'Robbins Principle', which stated that access to the entirely publiclyfunded universities should be available to all qualified students regardless of social background (Great Britain: Committee on Higher Education 1963, 8). This revolution in higher education policy unleashed a tidal wave of change upon the education system and the nation as a whole: new universities were created, some existing institutions were promoted to university status, and the research councils arose.

The Robbins Principle also reflected changes in British business culture, which continued moving towards a more meritocratic system of recruitment and promotion which took decades to play out. Later commentators such as Layard et. al. (1969) and Carswell (1985, 63) have written that in the immediate aftermath of this report little genuine change took place, but one outcome that did directly result from this period was the establishment in London and Manchester of the country's first two postgraduate business schools loosely modelled after American examples. By examining the national socio-political environment that produced these two schools, this paper examines the project to create a new type of British manager but not from the perspective of management educators themselves. This is because educators themselves did not financially support the two new schools nor sponsor the initial students who enrolled on their courses. This paper instead focuses on two other key groups of protagonists in the drive to expand management education: businesspeople and government officials. This new and unexplored perspective sits at the heart of the question of who these groups hoped and 
intended the new managers to become through their combined sponsorship of the two new institutions - responsible corporate citizens acting both for shareholders but also with the greater needs of society in mind. In light of the criticisms of management education levelled against it during the past decade, seeking the views of those outside the academy about who or what they hoped to create seems apropos.

These new managers were to be produced by an expanding hierarchy of management education provision led by the postgraduate business schools and included other universities, polytechnics, further education colleges, private providers, and in-company training programs. At the top of the pyramid, graduates of the new business schools would be capable of dealing with the increasingly complex organizations of the time and fulfilling important roles in society. Who did management education promoters imagine these new managers would be?

Answering this question requires understanding the background behind the business school project that had been simmering for several years but which emerged into the public eye as a result of the Robbins Report's publication. The two new business schools, the London Graduate School of Business (LBS) and the University of Manchester Business School, opened in 1965and quickly became leaders during the next twenty years of British management development. Together they helped to crystallize a national structure that enabled the vast multiplicity of other management education and training programs to slot into place beneath them. By setting the bar, a hierarchy eventually emerged of the substantial provision already available in this arena (Political and Economic Planning 1966, 262). The schools set out to provide advanced management education leading to a postgraduate degree and offered advanced post-experience courses. The widespread political acceptance of the Robbins Principle became the fulcrum by which management education advocates transformed a poorly-organized sector into a more hierarchical and purposeful one. The British management education environment required this reorganization to keep pace with competitor countries in 
Western Europe and North America, but also to attempt to settle a decades-long argument about the role and purpose of business leaders in British life. While activity expanded considerably in the further education sector during this period, this paper concentrates on university-level management education because within one generation this became Britain's dominant form of business education (Wilson and Thomson 2006, 171; Workman 2004; Sanderson 1972).

After explaining the historical context of this shift in management education in Britain, we explore some of the public debates themselves and seek to understand how those involved with the project outside the university sector understood it. These events represented the culmination of at least two decades of building pressure from various segments of society who wished to see Britain's managers elevated to a higher social standing (e.g. Urwick 1962) and the performance of British management improve after wartime weaknesses emerged (Brech 1999; Tiratsoo and Tomlinson 1993). The paper finishes with some conclusions about the effort to establish management education in Britain during the 1960s and what management advocates wanted to create through their labors.

\section{Historiography of British Management Education}

The financial crisis of 2007-08 re-invigorated long-running criticism of business schools and blamed them for being part of the problem that created the crisis. Allegations of management education's insufficiencies go back further in time, and were present during the foundation of the new business schools in the 1960s (Larson 2003). A short time later, another wave of criticism focused on how business education led graduates to have unjustified views of their own worth to the firm (e.g. Roeber 1971; Wills 1971; Mosson 1972). After a boom in UK postgraduate provision during the 1980s the decade starting in the mid-1990s saw concerns among management educators about the divide between theory and practice in management education (e.g. Clinebell and Clinebell 2008; Mintzberg 2004). It also saw the first serious attempt at an institutional history of one of the first UK business schools (Wilson and 
Manchester Business School 1992). ${ }^{1}$ The financial crisis shifted emphasis to decry a lack of 'responsible' or 'ethical' curriculum content in major business schools across the AngloAmerican landscape (Locke and Spender 2011) and some propose remedies (e.g. Amann et al. 2011). Volumes have been written criticizing mainstream business schools for their disconnection to business realities and questioning their value to society (e.g. Khurana 2007; Morsing, Sauquet Rovira, and Community of European Management Schools. 2011). In the UK context, authors such as Ken Starkey and his collaborators have been highlighting concerns about the business school sector (Starkey and Tiratsoo 2007; Starkey and Tempest 2008; Starkey and Pettigrew 2016; Starkey and Thomas 2019). Repeatedly, calls for business education reform have resounded in academic and professional journals advancing, elements of the Critical Management Studies agenda (Perriton 2007). These criticisms follow the line of condemning a neo-liberal economic hegemony that has infiltrated business education and confers status only upon satisfactory performance metrics without adequate consideration for other elements, such as maintaining employment, long-term viability of the firm within its environment, and the relationship(s) between the firm and the community. Such calls for more responsible business educations are worthy of scrutiny because they show that for the UK the discussion about the purpose of management training has come full circle. The voices not heard clearly in the above discussions are those of the businesses who hire the graduates and the government, responsible for funding the expanding business school sector. This paper returns to the establishment of postgraduate management education in the UK to examine what the non-academic founders of the first British business schools had in mind when starting the schools.

\section{The Context of Change}

While the Robbins Report represented a momentous adjustment in the trajectory of British higher education, it was not alone in contributing favorably to the environment in which the 
management education project operated. A variety of additional factors conspired to make the decade from 1955-1965 a propitious time for this initiative. First, a bulge in the birth rate immediately after 1945 had produced a surge in the number of children rising through the school system who would hit further or higher education in this period. Second, the trend of overall population growth required more capacity in the higher education system. Third, nearly a decade of Conservative Party rule starting in 1951 meant that both major parties were eager to put forward fresh polices to inspire voters and demonstrate their ability to govern: thus the ‘politics of modernization' were born. Finally, the British Productivity Council named 1963 as a 'national productivity year', accompanied by publications and events aimed at revitalizing the drive for higher productivity. Thus by the early 1960s much public and government attention focused upon the performance of businesses and their managements.

In light of these events, but especially because of the bulge in the birthrate and the trend for additional education, in February 1961 the Government organized the Committee on Higher Education under the Chairmanship of Lord Lionel Robbins. It asked the Robbins Committee to investigate the long-term future of higher education and make recommendations to account for these factors. The combination of these factors permitted many more people to acquire qualifications entitling them to attend university. Lord Robbins came to this Chairmanship from an academic position at the London School of Economics and the very fact that an economist was thought appropriate to advise the government on higher education policy strongly suggests that the Government believed in a positive correlation between investment in education and economic performance (King and Nash 2001). The Robbins Report explored connections between education and economic growth in some detail, and management education advocates shared this fundamental belief (Layard, King, and Moser 1969; Howson 2011; Watson 2014).

Parallel to this ran another phenomenon that came to be called 'declinism' (Collins and 
Robbins 1990; Supple, Clarke, and Trebilcock 1997; Tomlinson 2000). 'Declinism' represented a combination of factors including an economic slow-down in the later 1950s as domestic reconstruction played itself out, the unravelling of the British Empire and its preferential trading relationships around the world, and uncertainty regarding Britain's ability to join the European Economic Community. It is clear that Britons understood this phenomenon and its potential implications at the time both inside ${ }^{2}$ and outside of government (Ackers 1965). These factors resulted in the creation of the National Economic Development Council (NEDC) and "indicative economic planning" in 1962. The experiences of British businessmen with management education at prestigious US business schools encouraged some of them to seek to develop a parallel institution. Finally, the relatively low status of business careers in Britain was interpreted by some as the reason that business was not attracting its share of the best graduates into British companies (Vane 1958; Kipping 1972, 195-6; Wilson 1996, 134). During this time women's participation in this level of management education was nearly non-existent.

British universities had traditionally looked askance at management education as both purely vocational but also as devoid of its own independent body of knowledge which would clearly separate it from other disciplines in the social sciences and engineering (Keeble 1992; Allen 1961; Sanderson 1972, 305-10); officials in Whitehall expressed similar opinions more privately. ${ }^{3}$ Contemporaries struggled to define what the subject of management actually was. A third concern was that due to the national university funding model, few precedents existed for external parties such as wealthy businessmen or firms to donate money to establish professorial chairs or research centers for the pursuit of business studies (Larson 2003). This did happen in various ways from time to time: for example Nuffield College, Oxford, was designed to "encourage postgraduate research...[and make] easier the cooperation especially of academic and non-academic persons." Nevertheless, the problem of eventual assumption by 
the state of the cost of the venture restricted long-term options. ${ }^{4}$

British skepticism about the existence and contents of an academic field of management persisted into the post-war period. Businessmen and academics alike agreed that economics should play an important part in business studies, but as a discipline economics could not provide real-world solutions to specific business problems (Sanderson 1972, 188-9). Other disciplines such as organizational psychology, political science, industrial engineering, and accounting also appeared frequently in courses designed for intending managers (Williams 2010, 48). ${ }^{5}$ The application of various theories and disciplines in a coordinated way to unravel practical problems may have offered pragmatic solutions but seemed difficult to learn and even more complicated to teach. In the mid-1950s, commentators in the press often asked "what exactly is management?", a question which those active in the management arena struggled to answer (“The manager's bookshelf” 1957; Christopherson, Revans, and Shone 1955; Cook 1955). Many mainstream British educators, therefore, shied away from management education and employers often openly disdained it. This happened at two different levels. In 1966 the book Thrusters and Sleepers pointed out that some companies simply refused to accept that there was a management problem to address (e.g. Political and Economic Planning 1966, 51). Other firms, especially quite large ones, ran their own internal training and development programs, thereby eschewing external education offerings, and felt confident that in-house programs served their needs adequately. A small minority combined a number of methods in the hope that effective managers would somehow emerge from the plurality of programs they offered (Political and Economic Planning 1966, 50).

Regardless of the approach individual companies took, reliance upon traditional methods of identifying future management talent gradually ran out of steam in the 1950s and by the dawn of the 1960s some leading businessmen and politicians regarded more formal preparation for careers in business as a top priority for the nation (Larson 2003). These previous 
methods included apprenticeships, family relationships, attendance at elite schools or universities, and achievement of professional qualifications in a cognate field such as accounting or engineering; but most commonly the managers of large companies responding to a major survey in the mid-1950s had no qualifications at all (Acton Society Trust and Stewart 1956). Another survey undertaken in 1960 reported the well-established apprenticeship method to be the least successful avenue to senior management posts. Instead, the latter survey highlighted the growing role that formal education had played in determining an employee's place in the firm. Ambitious young workers took part-time courses to learn specific skills to increase their potential (Liverpool University et al. 1960, 73) including the British Institute of Management's (BIM) faltering Diploma in Management Studies. In 1949 the BIM created the Diploma course to provide more formal training to practicing and prospective managers. In the end the disadvantages of previous methods became more evident as the post-war era continued: long seniority within a single firm often resulted in a resistance to change. Growing firm size and the advancing technological complexity of products, manufacturing processes, and competition made it much more difficult for the experienced amateur to lead a firm successfully. Large firms moved to recruitment and promotion committee structures which reduced nepotism (Acton Society Trust and Stewart 1956, 7). Formal educational preparation for management, boosted by the growing belief in the ability of scientific solutions to improve society, offered an appropriate way forward for the country to develop managers in sufficient numbers to supply business needs. Increasing faith in a rational approach to political economy blossomed in the early 1960s fueling the 'scientization' of British society through the rest of the decade (Liverpool University et al. 1960, 64). Management education participated in and benefitted from this process.

Long-running concerns on both sides needed to be overcome. Businessmen and academics often found themselves on opposite sides of a debate about the usefulness of 
university-level education for business management (Locke 1985, 183; Wilson 1996, 134-5). From the beginning of the century university educators had snubbed business, because of its underlying profit motive (Keeble 1992, 79). Even as late as 1961, some deplored the idea that universities might be used for research projects aimed at solving the technical problems of a specific company or industry (Allen 1961), though such voices as these often had equally strident challengers. Manufacturers felt that much university teaching was not only slanted against careers in industry but that it often proved useless in the business world (Keeble 1992, 65). Though these sentiments were declining among larger firms, such tensions had previously generated long silences between academics and businessmen. It was only the initiative of motivated individuals or exceptional firms which overcame such differences. The development of management education in Britain reflects this larger pattern.

The rest of this paper will lay out two key debates which contributed to the creation of a new brand of businessperson. There were three elements that most management training advocates agreed upon. First, it was widely assumed that this would be largely, if not exclusively, a male domain. Women were specifically mentioned in the 1963 Franks Report Manchester but female participation in postgraduate management education remained low. Second, while individuals occasionally dickered about the details, nearly everyone agreed that students seeking management education should have several years of experience in the business world and be between 27-35 years old. Finally, strong feeling emerged about the idea that candidates for management education programs should be young men identified by their firms for potential advancement. Management education was not to be for so-called "diplomahunters" (Clarke 1956, 102) who were unlikely ever to exercise authority in a company; instead it should be directed at enhancing the skills and knowledge of those who companies had designated as potential 'high flyers'. Concerns about elite social reproduction notwithstanding, advocates felt that these conditions could optimize the utility of the limited resources available. 
With these similarities in mind, we look next at two key debates that shaped the landscape of management education in Britain.

\section{The Key Debates}

From the middle of the 1950s through the early 1960s British industrialists, academics, politicians and their civil servants began to think carefully about the needs of the nation's future managers. As several other authors have shown, careers in (especially) manufacturing industry did not hold high status in British society in the early decades of the twentieth century (Kipping 1972; Shaw 1995; Wilson and Thomson 2006; Child et al. 1983). Sweeping changes in the immediate post-war years solidified business opinions when the Attlee Labour Government nationalized a number of industries. While one or two of these returned to private ownership when the Conservatives returned to office in 1951, Labour's nationalization program inadvertently united much of British industry against government intervention in its affairs. This atmosphere explains the impotence of Labour's BIM in promoting improvements among British managers and the disappointing track record of its main qualification, the Diploma in Management Studies (Clarke 1956, 101; Clark 1966, 125; Robertson 1970). ${ }^{6}$ Numerous seemingly independent attempts to redress the perceived deficiencies of British management arose during the $1950 \mathrm{~s}$ in addition to the Diploma scheme to create a variety of programs offering some kind of management, business, or commercial training. The socio-political environment also inspired business leaders and politicians to consider what they wanted from future managers. Disagreement appeared immediately about some key issues.

In this way two major debates emerged. The first concerned the question of what should be taught and the pedagogical level(s) of management education. The second debate was more important, as it concerned the ultimate purpose of management education in society and how the next generation of managers should be trained. This incorporated a discussion about the fundamental role of the business manager in society. The remainder of the paper addresses 
each of these points in turn.

What should be taught: general education vs specific technical competences

An increasing specialization in education leading to functional expertise in relatively narrow areas troubled some businessmen. A variety of voices called for management education providers to offer a broadening of vision and attempt to convert the functional subject specialist 'back' into a well-rounded generalist (Liverpool University et al. 1960, 67-8; Smith 1961, 89; Hall 1964, 113). Clarke cited Professor Ronald S. Edwards's support for the idea that "the important point is the level at which the subjects are studied and whether they develop the mind, the judgment and the character of the students", strongly suggesting a desire for more than technical competence in a specialist field (Clarke 1956, 104). Characteristically taking things a step further, in 1962 Foundation for Management Education (FME) chairman James W. Platt spoke at a conference on the future of management education. He noted that as Britain's political environment had changed, the needs of business shifted also. The previous year, Chancellor of the Exchequer Selwyn-Lloyd had established a new tripartite body involving government, business, and labor unions called the National Economic Development Council (NEDC) to coordinate economic planning for the nation. Platt explained that the intended economic coordination between government and business through the NEDC meant that the businesspeople needed "wisdom and statesmanship...of a new order" compared with the past. $^{7}$ The academic disciplines which contributed to most management education programs, such as economics, sociology, psychology could not individually create the 'statesman-businessman' that Platt envisioned.

Others however applauded the acquisition of specialist skills by managers, especially top managers, explaining that on the one hand educational qualifications contributed to justifying management's claim to authority over the work process, while on the other saying that in the increasingly complex and competitive environment, acquiring technical skills 
enabled the executive to comprehend the industry and its changing dynamics better. The push for justification of authority came in part from the early 1950s drive for increased productivity (for more, see Carew 1991; Tomlinson 1991; McGlade 1998). It is not surprising that the third most popular productivity report in terms of circulated copies was Management Accounting (Anglo-American Council on Productivity 1952, 37). Graham Hutton, summarizing the work of the Council that great attention appears to have been paid to the 'management education' team and its report (Hutton 1953). Although more critical comment on Hutton's views appeared much later (Tiratsoo and Tomlinson 1993), some evidence exists that contemporaries valued these reports (Anglo-American Council on Productivity 1952, 30). A related impulse came from the labor market that existed during the 1950s. In an era of virtually full employment, relations between trade unions and management emphasized the importance of managerial knowledge of industrial psychology or sociology. Still another driver for specialist skills arises from the possibility that existing managers themselves grew concerned at their lack of formal qualifications and used relevant education to bridge this perceived gap (Clark 1966, 134). If nothing else, as one report on a management survey suggested, "appeals to a Divine Right [to manage] are unlikely to be widely accepted, and the substantial separation of ownership from control makes the appeal to traditional property rights less valid. Thus the justification must be made in terms of the senior managers being the most able persons for the position in the community..." [emphasis added] (Liverpool University et al. 1960, 70).

The Second Report of the United Kingdom Advisory Council on Education for Management also pointed out the benefits of a solid grounding "in the most fundamental subjects - facility in the use of language and an understanding of mathematics", as mathematics was required both to understand accounting figures as well as production statistics accurately. ${ }^{8}$ More broadly, Thrusters and Sleepers asserted that specialist knowledge bases had a secure place in the toolkit of future managers, noting that "rapid changes in both management 
techniques and industrial processes are now normal and managers should ideally have some appreciation of the forces and trends of scientific development which are at work" (Political and Economic Planning 1966, 260). These arguments clearly show that some specialist training could be very useful in this regard and should not be completely abandoned.

The Education Committee of the Federation of British Industries (FBI), and the FBI overall, fully engaged in the management education debates. The FBI Review included articles that outlined a desire to see evidence of a broad-based education in management candidates. ${ }^{9}$ The FBI's Education Committee prepared a report in light of the National Economic Development Council's publication Conditions Favourable to Faster Growth in 1963 (Federation of British Industries 1963). Talking less about the need for a general education on this occasion, the FBI "emphasized attitudes of mind rather than techniques" and hoped that the educational system could "create situations in which attitudes could be developed". ${ }^{10}$

Other voices also talked about changing attitudes among up-and-coming managers. J. MacKenzie wrote in the BIM's magazine The Manager that he wanted to "question the implication that management attitudes and actions are themselves beyond reproach or criticism. And I shall concern myself particularly with the younger men [sic], since the country's capacity to survive the competitive conditions now arising lies largely with them." (Mackenzie 1961, 852). Likewise, The Statist ("Managing Training for Management" 1963) highlighted the difference in attitudes between American and British managers: "America's highly developed schools of business are turning out first-class management material, and from the best of these schools the graduates emerge with both a broad education and a 'professional attitude to management"' [emphasis added]. This latter concept equated to the 'disposition' element referred to by Hall above.

Likewise, the support arm of the NEDC prepared comments for its director, Sir Robert Shone, before he met in person with Lord Oliver Franks, who had been asked to arbitrate the 
management education question in 1963 (Franks and British Institute of Management 1963). Shone sought to offer his organization's perspective on the future of the business school project. The brief explains that management teaching in the past had "not been the right kind of teaching - it has aimed at teaching existing knowledge about established disciplines rather than at developing managerial skills and executive ability". ${ }^{11}$ Both this document and the FBI report above skirt the issue somewhat in their indirect language, with one talking about 'attitudes' conducive to business, and the other mentioning the desire to develop 'executive ability', however they construed it. The issue of changing attitudes through formal education arose again in a report about a tour of American business schools written by Office staff member Mildred Wheatcroft (Wheatcroft 1970). One section of her lengthy report focused on the executive-level training provision with the blunt comment that "Sometimes the objective is to change fixed attitudes" in US business schools rather than to teach disciplinary knowledge. ${ }^{12}$ As shown above, representatives from the BIM, the FBI, and the NEDC Office agreed with the desire to change attitudes in British business, perhaps by using formal management education.

The Ministry of Education and the University Grants Committee (UGC) recognized that students graduating from English universities struggled to find the positions in business that they desired if they studied business management. As a department of the UK Treasury, the UGC served as a direct funding body for universities throughout this period, while the Ministry oversaw lower levels of education. University appointments boards knew well that businesses "do not want to recruit graduates with first [i.e. undergraduate] degrees in business management; they prefer a graduate with a broader education whom they can subsequently train for management either within their businesses or in postgraduate study in the universities and college or both." 13 Traditionally this broader education had come through the Arts faculties. Such views had not changed significantly since a 1945 report by the University of 
Cambridge Appointments Board admitted that few of the most able university students seriously considered jobs in business and management, preferring instead more typical careers for university graduates in Britain such as government service or academic positions (University of Cambridge 1945, 7; Keeble 1992, 78-80). Such positions usually brought higher status to a graduate than a career in business.

Finally, in its annual report for the years 1964-65, even LBS itself mentioned the importance of, and industry's desire for, a broad education in favor of a narrow specialist one. The statement came in the context of differentiating between graduate and undergraduate education, where the report claimed that a specialist undergraduate degree in management must come at the "expense of a more liberal education which is a valuable foundation for any type of managerial activity". ${ }^{14}$ Taken together, the variety of voices heard and the broad range of sources from which this evidence comes show that the debate about the type of education was settled in favor of a broader one at least for senior management roles. The integral part some of these individuals and institutional bodies played in establishing the norms of management education demonstrates the premium placed upon educating prospective managers quite widely so that they would not be limited by specialization into particular functional or disciplinary areas. This breadth was intended not merely to strengthen the firm's performance or enable managers to represent the firm more effectively outside the organization. Instead, some management education advocates during this era had even grander visions about Britain's future managers.

\section{The role of managers in British society}

During the late 1950s into the middle of the 1960s, several businessmen in the biggest British firms dedicated substantial time and effort to improve the management talent at the top of the nation's leading companies. To that end, management education promoters argued that a broad liberal arts education, of the kind offered by the fee-paying Public Schools and the old 
universities at undergraduate level, combined with real experience in business, built the foundation for a higher managerial career. This specific vision of a managerial career differed sharply from continental European examples such as Germany where managerial careers frequently rested upon expertise in functional areas (Stewart et al. 1994). It also differed starkly with American practices where large numbers of undergraduates received undergraduate degrees in business before actually entering a firm. Both visions contrasted with Britain's traditional routes to senior managerial positions, which no longer relied strongly upon familial relationships and began to move away. It began also to eschew the tradition of promoting accountants or engineers into senior positions by focusing the content and aim of management education towards the creation of a broad-minded general manager without focus upon any one functional area.

What is even more noticeable about this move towards using formal education to prepare top managers for their future roles is the clear recognition among the promoters of management education of the role that such men would play in securing the nation's future economic strength. This ran in two directions; the predominant direction was that the mantle of responsibility lay across their shoulders and the proper preparation for accepting this responsibility was vital for the national wellbeing. The second direction, though, appeared to demand a certain status from society in exchange for carrying this burden of generating the nation's wealth in an increasingly complex and competitive international marketplace. Let us deal with the latter idea first and then come back to the crucial notion of the responsibilities of the business community.

\section{Reflecting the desired status}

In the construction of the business schools, there were clear references throughout to expectations that businessmen had regarding their status and the kind of environment that they demanded. People recognized that status and prestige flowed in both directions: a prestigious 
business school attracted the best candidates and powerful executives; the presence of the best people or companies generated esteem for the business school. In this way the Henley Administrative Staff College had risen during the 1950s to become the most respected management training center in England (Clark 1966, 132). Thus some felt that status weighed particularly heavily in this sphere of activity. Businesspeople expected the schools to provide the same quality of facilities that business offered its own senior executives; officials in Whitehall resisted this view, especially for postgraduate students. The business school promoters had high aspirations, which may not have surprised anyone; Whitehall officials quickly realized the growing cost of these aspirations. Secretary of LBS, William Barnes, a civil servant seconded to LBS from the Board of Trade, earned criticism from other departments for his "very grand ideas" about the standard of furniture and fittings for the School. ${ }^{15}$ As a career civil servant in a business-related department, perhaps Barnes understood only too well the social aspirations that business school promoters held for the students. Throughout the negotiations surrounding the preparation of LBS in particular, the most heated discussions concentrated upon the residential accommodation. Given the space available, LBS's Planning Board under Lord Plowden wished to increase the number of student studybedrooms from the Franks Report figure of 150 to 200. The University Grants Committee did not criticize this except to say that it provided more bedrooms than the number of students the School was allowed to teach. In light of LBS Principal (and former Canadian businessman) Arthur Earle's proposition to double the length of the postgraduate course to two years, this proposal makes more sense.

Of all things, the number of bathrooms proved to be a sticking point in discussions about the renovation of the building that would become the permanent home of LBS. While in one sense a mere footnote in history, the debate between industry and government about this matter took on a highly symbolic quality, emblematic of many elements of the entire project. 
The UGC held that LBS required nothing more than any other graduate-level institution country. Normally the UGC stipulated one bathroom for every five beds; the LBS Academic Planning Board insisted on a bathroom for every bedroom, especially in the post-experience wing. Whitehall officials expressed astonishment at this extravagance. Carswell graphically portrayed the strength of feeling demonstrated in this discussion, writing that "teacups bounced on the table with the impact of Lord Robens of Wolsingham's fist reinforcing his requirement that the UGC capital grant should allow for a bathroom for every student of the London Business School. The UGC had thought one for every four would be generous" (Carswell 1985, 63). Robens served as head of the National Coal Board from 1961-71 and as chairman of Council for Manchester Business School from 1970-79; pounding his fist on the table emphasized his strong feeling that these students deserved special status apart from normal postgraduates in other fields.

Similarly, business's desire for on-site car parking became an issue in Manchester. The additional cost was estimated at $£ 1000$ per parking space; the justification for the expense was that "the business men [sic] will expect it". ${ }^{16}$ Comments flew within and between government departments about the need to curtail the "expense account" lifestyle advocated by industry for students at the Schools ${ }^{17}$ even though it was precisely this "expense account" lifestyle that business thought the schools were preparing students to enter. Lord Plowden later argued that LBS's post-experience students would range from young 'high-flyers' to senior people in British business accustomed to having 'luxuries' like private bathrooms wherever they travelled. Plowden also pragmatically appealed to the UGC's pocketbook. First, LBS intended to charge substantial fees for its educational offerings and students seconded from industry expected high standards both in the classroom and in other facilities in exchange for these fees. Second, he explained that during academic vacations the ability to let en suite rooms in central London would be much greater and more remunerative than rooms without their own facilities. 
Third, he realized that much management preparation at Britain's largest companies had taken place in large, well-furnished country houses in rural settings; this had been industry's accustomed environment for training its prospective managers, so the new business schools should seek a similar type of atmosphere. In the end, they reached a compromise whereby the post-experience wing of the building included a bathroom for each bedroom, while in the postgraduate wing the standard UGC ratio of one bathroom for every five students remained. Barnes confirmed years later that the en suite rooms were profitably let during vacations; but the postgraduate rooms with shared bathrooms proved harder to fill (Barnes 1989, 56).

This clash with officials over accommodations at LBS helps us understand the depth of feeling held by some of the business leaders who played pivotal roles in constructing the Schools and their vision of the overall purpose of management education. Their behavior suggests that they felt they were building a flagship institution for the future that would inspire both the current generation of middle and senior managers in British business and the generations of business leaders coming through as graduate students. Business school supporters within industry wanted to provide a comfortable and acclimatizing environment for serious learning that would demonstrate industry's support.

\section{Roles of responsibility in British society}

Government also had a strong interest in the abilities of Britain's managers. Several senior politicians in early 1964 watched developments carefully and wanted to be kept aware of progress within the management education project even when their official portfolios were not related to these developments. NEDC and the Treasury's University Grants Committee, as mentioned earlier, were deeply engaged with this topic in Whitehall. ${ }^{18}$ The document concluded that "there is a great deal of enthusiasm and pressure" for management education, an idea confirmed later by former Treasury official John Carswell: "There was more pressure on their [the business schools'] behalf than for any of the other novelties [emerging from the 
Robbins Report], and there was a feeling, too, that here at least part of the cost would be borne by the direct beneficiaries - business itself and the individuals receiving the prestigious qualifications the schools would bestow" (Carswell 1985, 63). Perhaps it was the point about the possibility of sharing the cost of education with other sectors in the society that piqued the interest of the politicians. Carswell mentions some complications as well. He noted that some other Robbins innovations were not realized, in contrast to the two business schools. Other concerns included possible duplication of effort as factions scrambled for position and prestige, lingering tensions between academia and industry, and the desire to wait until the Heyworth Committee on Social Studies reported because its remit included the component disciplines of management education alongside other fields in the social sciences; eventually this process resulted in the formation of the Social Science Research Council (King 2011). It seems unlikely that so many high-level ministers and politicians would be interested in management education if they did not believe it would have a significant effect on the nation overall. From the perspective of influencing future generations of British businesspeople, both political leaders and civil service mandarins felt it worth their while to monitor its progress and provide encouragement.

The FBI also saw the relevance of management education and actively kept abreast of, and occasionally originated progress in, this area. The Director-General from 1945-65, Sir Norman Kipping, expressed this to BIM Director John Marsh in June 10, 1963. An earlier letter from Marsh noted concerns about possible overlapping interests and responsibilities in the management education arena, and Marsh had asked Kipping whether it would not be better for the BIM to take the lead given its raison d'etre. In attempting to reassure Marsh that the FBI intended to push things forward in partnership with the BIM, Kipping wrote

“Don't worry - there's no conflict [between our organizations] ...It is quite impossible for the FBI to keep out of this subject. Saturday's leader in The 
Times, Monday's Panorama Programme, next month's Times Review of Industry, the impending Robbins and Crick Reports, NEDC, etc., etc. are all rightly - and welcomely - making this subject topical and newsworthy. The FBI would be open to quite justifiable criticism of dragging its feet, being out of date and all that sort of thing, if it were not up with the leaders on a topic of such importance." 19

Kipping's letter reflects that the mainstream press and its own industrial membership expected the FBI to have carefully considered opinions on the issue. The FBI felt confident in offering its opinions without consulting with the BIM. Nonetheless, Kipping understood that partnership would be more productive than competition and worked with the BIM in this area.

Six months later, the FBI Education Committee held a meeting in which a similar concern about long-run consequences arose. The Committee discussed what they saw as a decrease in so-called 'sandwich courses', in which a student undertook a period of study, then returned to the business world for additional experience and then resumed academic study to finish the qualification. The Committee minutes record that "the greater maturity of students who had gone through the sandwich training was marked" and that there was the "utmost need to retain the sandwich principle. The social revolution, which had taken place, must be understood by management and the essential training provided." 20 The 'social revolution' referred to changing demographic trends which in subsequent years would witness the 'baby boom' generation coming of age and entering higher education and the workforce. Business failure to address the needs of this large cohort of future workers and managers would spell disaster for Britain's long-term economic prospects. Industrialists understood well that there might be dire consequences if adequate preparation for working life was not offered to the next generation.

In a similar way, Canadian businessman Arthur Earle, selected as the first Principal of 
LBS because of his extensive business experience, understood that decisions made about the style and orientation of the business schools could also have long run social consequences which required consideration in the present. Earle proposed immediately that LBS should have a two-year course, more closely following North American examples. This concern addressed the long-term ability of LBS to do its job. He added that the business schools had been intended to create better businessmen for British firms, and he argued that a two-year course would create "very much better men" than a one-year course, even if student numbers were reduced to compensate for doubling the time required to produce them. He rhetorically asked "If it is not the job of the business schools to produce such top quality men, then the question must be raised as to whose job it is." 21 This was undoubtedly a question to which some in the business community would have replied without hesitation that it was each company's job to train its own personnel, and was not something that formal education could address. Nonetheless, Earle viewed LBS as the premier management education offering in the country once it opened, playing a pace-setting role for Britain in the years ahead.

Individual industrialists occasionally weighed in on these topics also. An example is found in Sir Archibald Forbes, who in 1963 was chairman of the Central Mining Investment Corporation, deputy chairman at Midland Bank, and member of several boards of directors of large British companies. Forbes articulated his understanding of the public responsibilities of business managers in the following way:

“...the public accountability of business management stems from the fact that efficiency of business operations is fundamental not only to commercial success but to national prosperity. Efficiency in this context has to be interpreted in the fullest sense. Ideally it would connote that under competitive conditions there is the best utilization of resources by the most modern methods allied with adequate research and inventiveness - the whole being designed to provide 
good and stable employment and fair return to the investor of capital." 22

Forbes's view clearly places the industrial manager in a key position in a capitalist society, because this man must run his business as efficiently as possible to serve both private interests as well as the interests of the nation. Forbes did not extend beyond the capitalist economic system as he understood it: the job of a manager was to maximize the use of resources for the benefit of all, but not surprisingly for the benefit of the shareholder or investor in particular. Forbes, unlike some other industrialists who were actively promoting management education, was not one of its key advocates, yet his perspective echoes some of the underlying philosophy of the project. He wished to promulgate this sense of responsibility to society through the best available education of managers.

Surveys conducted at this time allowed similar voices to express themselves. Respondents to the Political and Economic Planning survey Thrusters and Sleepers questioned openly whether there was not more to management than simply making money. One respondent replied that the object of running a company was about providing a service and employing people to offer them a livelihood: "I mean the whole country runs on industry.....and a firm has to do its best in keeping the country going, providing the livelihood for the citizens" (Political and Economic Planning 1966, 44). A similar sentiment came from another respondent, who saw multiple responsibilities for the manager such as himself: duties to the shareholders, to provide meaningful work to the employees, and to help the employees "get something out of life in the process" even while advocating hard work and efficiency on the job (Political and Economic Planning 1966, 44). These perspectives demonstrate that the sentiments the management education advocates sought to teach already existed in some spheres of British management thinking.

Finally, it may come as little surprise that FME leader James Platt was even clearer about the purpose of creating a high-quality manager through the management education drive. 
Speaking in 1962 he told his audience that businesspeople of tomorrow "must recognize the responsible place which they occupy in the overall policy of Government, and yet demonstrate effectively by their personal standing and their professional competence" that they can adjust to the times and the political environment in which they operate. ${ }^{23}$ This clear call for the business world to understand and accept its 'responsible place' in the life of the nation came as the management education project began to accelerate. The statement demonstrated a recognition by one of the project's main leaders that business did and should play a key role in society but must do so in partnership, rather than in conflict, with government.

In the same speech, Platt laid out the wider importance of this partnership. He said that "business must consider its social responsibilities, and the part it can play in the better ordering of society. This applies not merely to hours of work and conditions of work, but to the broader changes in human standards and values, to education, to equality of opportunity, and in general to the dignity of the individual man." After mentioning the importance of delegation of authority, and the consequent importance of proper training of those to whom power is delegated, Platt made a crucial point in exploring the relationship between management and society more generally:

There are thinkers in Europe who would take this point even further. They link it with the preservation of European humanism which sets the criterion of progress as the fulfilment of human personality. They believe that men in positions of higher responsibility, through their direction of important enterprises, and by their general influence, play a crucial part in defining man's place in society, and in giving meaning to human dignity. In this sense it can be said that every organization, and every executive, can have a cultural role.

Platt's argument brought businessmen and managers to the center of a discussion about the character and direction of society, and in doing so re-emphasized the theme of management's 
perceived need for a broad general education instead of a narrow functionalist one. Platt himself was a major contributor to the effort to establish high-level management education in Britain, and this philosophy clearly informed his thinking before the Robbins Report appeared and before interest in developing management education gained widespread traction in industry or government over the following eighteen months, which in turn led to the formation of the first two business schools. The remainder of the speech outlined a program for management preparation at various levels in the educational system, but such a clear philosophical argument highlights his passion for maximizing the potential of the nation's managerial talent and provides evidence of the long-term developmental work that management education promoters undertook during this period.

\section{Conclusions}

This paper has argued that the decade from 1955-1965 in Britain represented one of tremendous change with respect to how managers would be trained and the role they would assume in society. It has shown something of what British industrialists thought they wanted their managers to become, in large part through the process of management education and training. While the period of change finally culminated in the 1963 Robbins Report, which called for the establishment of two business schools, the educational climate had been warming to high-level management education for some time. Senior government officials and politicians watched its progress carefully. Business called for a broadening of knowledge so that future managers would not be locked into narrow functional specialisms, but could offer useful perspectives across a range of business activities within the firm and adroitly adjust to changes in the external business environment. To some extent this included elements of personality and attitude as much as managerial experience and competence. Increasingly businessmen and educators believed that management education could make adequate managers better, and thus impact the wider economic environment for the benefit of all. Promoters exhibited a 
preoccupation with the experiences and future success of large firms, but provision occurred across a large range of educational institutions available to many businesses. Finally, industrialists and their organizations understood very well the role that they wanted and needed to play in society. James Platt articulated this position in his speech but, as demonstrated in this paper, many others held similar views about the role of business in society and the social role of business leaders. Aside from some of the quotations from Thrusters and Sleepers above, Platt's colleagues within FME, several government ministers and Members of Parliament, and prominent industrialists such as Lord Plowden and Lord Rootes all sought both practical as well as more socially-oriented goals from the movement. Collectively, these advocates' efforts helped business enhance its standing in the national community and altered British society during the generation that followed, helping to produce a boom in management education by the 1980s.

These two debates link together closely. While the management education advocates clearly believed that a generalist education - at least at undergraduate level - would serve business needs well, they also felt that it provided the sort of broader intellectual training that would enable aspiring senior managers to become the combination of statesman and businessman of the sort articulated by people like Platt. There is no denying that a certain amount of specialist technical knowledge can be very helpful in business, but to become the future 'captains of industry', promoters argued that young men (and later women) must learn to think beyond the needs of the firm to incorporate the needs and concerns of the wider community. Yet they must do so proudly and self-assuredly, secure in the knowledge that society values their contributions and that their voices will be heard. In this way, the effort to enhance the status of business comes together with the content of management education to create a well-prepared and suitably informed leader who can adapt to changing circumstances and confidently take his or her place at the national policy table. 
A potential weakness of this study is that those strongly opposed to establishing new business schools in Britain did not record these feelings as well as those who supported it; one reason for this could be that those opposed saw the wide-ranging political and industrial support and decided not to oppose it vocally. Critics of the two business schools noted that their small student numbers were never sufficient to affect British business in its entirety, and thus claimed the schools' establishment merely served to satisfy the whims of some wealthy businessmen who wanted a legacy project to end their careers. Such a perspective would be misguided for the following reasons: first, government ministers would be unlikely to accede to such a costly plan if they really believed that it only served personal agendas rather than the national welfare. Second, considerable evidence demonstrates that the advocates genuinely believed what they said about the role(s) that a "managerial class" (Bosch 1964, 41) could and should play in British society, some of which appears in this paper. Third, as this paper shows, the London and Manchester schools became flagship institutions at the pinnacle of a management education hierarchy. By elevating management education to postgraduate degree level, its supporters showed that students of business could rise to similar educational heights as students in conventional subject areas.

\section{References}

\section{Archives}

The Modern Records Centre, University of Warwick

The National Archives, Kew Gardens, London

\section{Secondary Sources}

Ackers, James. 1965. "Our economic inheritance." Crossbow 9:45-7.

Acton Society Trust, and Rosemary Stewart. 1956. Management succession; the recruitment, selection, training, and promotion of managers. London: Acton Society Trust.

Allen, V L. 1961. "Management and the Universities - Part I." Listener.

Amann, W., M. Pirson, C. Dierksmeier, E. von Klimakowitz, and H. Spitzeck. 2011. "Business Schools Under Fire: Humanistic Management Education as the Way Forward." In. New York: Palgrave-Macmillan.

Anglo-American Council on Productivity. 1952. The Final Report of the Council. London; 
Washington, D.C.: Anglo-American Council on Productivity.

Barnes, William. 1989. Managerial Catalyst: The story of London Business School 1964-1989. London: Paul Chapman Publishing for London Business School.

Bosch, Henry. 1964. "A new deal for industry." Crossbow 8:37-42.

Brech, E F L. 1999. "Management History : An Introduction." Contemporary British History $13(3): 1-9$.

Carew, Anthony. 1991. "The Anglo-American Council on Productivity (1948-52): The Ideological Roots of the Post-War Debate on Productivity in Britain." Journal of Contemporary History 26:49-69.

Carswell, John P. 1985. Government and the universities in Britain : programme \& performance, 1960-1980. Cambridge: Cambridge University Press.

Child, John, Michael Fores, Ian Glover, and Peter Lawrence. 1983. "A Price to Pay? Professionalism and Work Organization in Britain and West Germany." Sociology 17 (1):63-78.

Christopherson, D G, R W Revans, and K Shone. 1955. "Training Science and Engineering Graduates for Industry." The Manager 23 (12):959-62.

Clark, David George. 1966. The industrial manager: his background and career pattern. London: Business Publications.

Clarke, David K. 1956. "A Survey of Management Education in the United Kingdom." Journal of Industrial Economics 4 (2):95-106.

Clinebell, Sharon K., and John M. Clinebell. 2008. "The Tension in Business Education Between Academic Rigor and Real-World Relevance: The Role of Executive Professors." Academy of Management Learning \& Education 7 (1):99-107.

Collins, Bruce, and Keith Robbins. 1990. "British culture and economic decline." In Debates in modern history, $\mathrm{x}+208$. London: Weidenfeld and Nicolson.

Constable, John, and Roger McCormick. 1987. The Making of British Managers, B.I.M. Survey. Corby, Northhamptonshire: British Institute of Management.

Cook, W R J. 1955. "Executive Development: Problems in Training Scientists for Management." The Manager 23 (12):1069-70, 88.

Federation of British Industries. 1963. "Management Education and training needs of industry: a report by an F.B.I. working party." In. London: Federation of British Industries.

Franks, Lord Oliver, and British Institute of Management. 1963. British Business Schools. London: British Institute of Management.

Great Britain : Committee on Higher Education. 1963. Higher education : report of the committee appointed by the Prime Minister, under the chairmanship of Lord Robbins, 1961-63. Edited by Parliament of Great Britain. Vol. 2154. London: HMSO.

Hall, Noel. 1964. "Education and Management." Journal of Management Studies 1 (2):10515.

Handy, Charles, Colin Gordon, Ian Gow, and Collin Randlesome. 1988. Making Managers. London: Pitman.

Howson, Susan. 2011. Lionel Robbins, Historical Perspectives on Modern Economics. Cambridge: Cambridge University Press.

Hutton, Graham. 1953. We too can prosper; the promise of productivity. London: Published for the British Productivity Council formerly the Anglo-American Council on Productivity (U.K. Section) by Allen and Unwin.

Keeble, Shirley P. 1992. The ability to manage : a study of British management, 1890-1990. Manchester: Manchester University Press.

Khurana, Rakesh. 2007. From Higher Aims to Hired Hands : The Social Transformation of American Business Schools and the Unfulfilled Promise of Management as a Profession. Princeton, NJ: Princeton University Press. 
King, Desmond. 2011. "The Politics of Publicly-funded Social Research." In A Manifesto for the Public University, edited by John Holmwood, 74-89. London: Bloomsbury Academic.

King, Desmond, and Victoria Nash. 2001. "Continuity of Ideas and the Politics of Higher Education Expansion in Britain from Robbins to Dearing." Twentieth Century British History 12 (2):185-207.

Kipping, Sir Norman. 1972. Summing up. London: Hutchinson.

Larson, Mitchell J. 2003. "Practically Academic: The Formation of the British Business School." Doctoral thesis, University of Wisconsin-Madison.

Layard, Richard, John King, and Claus Moser. 1969. The impact of Robbins, Penguin education special. Harmondsworth: Penguin.

Liverpool University, Social Science Department Industrial Research Section, Ian C McGivering, DGJ Matthews, and WH Scott. 1960. Management in Britain, a general characterisation, University of Liverpool, Dept. of Social Science, Social research series. Liverpool: Liverpool University Press.

Locke, Robert R. 1985. "The relationship between educational and managerial cultures in Britain and West Germany : a comparative analysis of higher education, from an historical perspective." In Managing in Different Cultures, edited by Pat Joynt and Malcolm Warner, 166-214. Oslo: Universitetsforlaget.

Locke, Robert R, and J-C Spender. 2011. Confronting Managerialism: How the Business Elite and Their Schools Threw Our Lives Out of Balance. London: Zed.

Mackenzie, J. 1961. "British Management in Blinkers?" The Manager 29 (11):853-4.

"The manager's bookshelf." 1957. The Manager 25 (11):897-901.

"Managing Training for Management." 1963. The Statist:563-4.

McGlade, Jacqueline. 1998. "The U.S. Technical Assistance and Productivity Program and the education of Western European managers, 1948-58." In Missionaries and Managers: American Influences on European Management Education 1945-1960, edited by Terry R Gourvish and Nick Tiratsoo, 13-33. Manchester and New York: Manchester University Press.

Mintzberg, Henry. 2004. Managers Not MBAs : A Hard Look at the Soft Practice of Managing and Management Development. Harlow, England: Pearson Education Ltd.

Morsing, Mette, Alfons Sauquet Rovira, and Community of European Management Schools. 2011. Business schools and their contribution to society. Los Angeles ; London: SAGE.

Mosson, T M. 1972. "And now a word from our sponsors..." Management Education and Development 3:74-8.

Perriton, Linda. 2007. "Really useful knowledge? Critical Management Education in the UK and the US." Scandinavian Journal of Management 23:66-83.

Political and Economic Planning. 1966. Thrusters and Sleepers: Attitudes in British management: a P.E.P. report, Pelican books, A825. Harmondsworth: Penguin.

Robertson, Andrew B. 1970. "Business Schools : Is the Backlash Justified?" Management Decision 4:12-5.

Roeber, Joe. 1971. "Crisis in business schools." In The Times Educational Supplement, 5. London.

Sanderson, Michael. 1972. The universities and British industry, 1850-1970. London: Routledge and Kegan Paul.

Shaw, Christine. 1995. "Engineers in the Boardroom: Britain and France Compared." In Management and Business in Britain and France, edited by Youssef Cassis, François Crouzet and Terry R Gourvish, 159-68. Oxford: Clarendon Press.

Smith, J H. 1961. "Management and the Universities - Part II." Listener.

Starkey, Ken, and Andrew Pettigrew. 2016. "The legitimacy and impact of business schools: 
key issues and a research agenda." Academy of Management Learning \& Education 15 (4):649-64.

Starkey, Ken, and Sue Tempest. 2008. "A clear sense of purpose? The evolving role of the business school." Journal of Management Development 27 (4):379-90.

Starkey, Ken, and Howard Thomas. 2019. "The future of business schools: shut them down or broaden our horizons?" EFMD Global Focus 13 (2):44-9.

Starkey, Ken, and Nick Tiratsoo. 2007. The business school and the bottom line. Cambridge: Cambridge University Press.

Stewart, Rosemary, Jean-Louis Barsoux, Alfred Kieser, Hans-Dieter Ganter, and Peter Walgenbach. 1994. Managing in Britain and Germany. New York: St. Martin's Press.

Supple, Barry, Peter F Clarke, and Clive Trebilcock. 1997. Understanding decline : perceptions and realities of British economic performance. Cambridge: Cambridge University Press.

Tiratsoo, Nick, and Jim Tomlinson. 1993. Industrial efficiency and state intervention : Labour, 1939-51. New York: Routledge.

Tomlinson, Jim. 1991. "The failure of the Anglo-American Council on Productivity." Business History 33:82-92.

2000. The politics of decline : understanding post-war Britain. Harlow, England: Longman.

University of Cambridge. 1945. University education \& business; Report by a Committee appointed by the Cambridge University Appointments Board together with a summary and analysis of evidence collected for the Committee. Cambridge: Cambridge University Press.

Urwick, Lyndall F. 1962. "Management's Status in Great Britain." Atlanta Economic Review:14-8.

Vane, Henry. 1958. "How will we Manage? British industry suffers from unimaginative recruitment." Crossbow 2:32.

Watson, David. 2014. "Robbins and His Children: the Theory and Practice of Higher Education Inquiries, 1963-2013." Higher Education Quarterly 68 (2):125-46. doi: 10.1111/hequ.12045.

Wheatcroft, Mildred. 1970. The Revolution in British Management Education. London: Pitman Publishing.

Williams, Allan P.O. 2010. The History of UK Business and Management Education. London: Emerald for the Association of Business Schools.

Wills, Gordon. 1971. "'Arrogance' of 'national' business schools attacked." In The Times Higher Education Supplement, 16. London.

Wilson, John F. 1996. "Management Education in Britain : a compromise between culture and necessity." In Management education and competitiveness, edited by Rolv Petter Amdam, 133-49. London: Routledge.

Wilson, John F, and Manchester Business School (University of Manchester). 1992. The Manchester experiment : a history of Manchester Business School, 1965-1990. London: Paul Chapman Publishing for Manchester Business School.

Wilson, John F., and Andrew Thomson. 2006. The Making of Modern Management: British Management in Historical Perspective. Oxford: Oxford University Press.

Workman, Joanne. 2004. "Paying for Pedigree? British Business Schools and the Master of Business Administration Degree." Unpublished doctoral thesis, University of Sussex.

\section{Notes}


${ }^{1}$ William Barnes, a civil servant seconded from the Board of Trade, served as the first Secretary of the London
Business School. In retirement he published a sort of memoir about the early years of that institution. While it was not a serious historical work, some of his observations are the only accessible record of certain events. (Barnes 1989)

${ }^{2}$ National Archives of the United Kingdom (hereafter NA), PREM 11-3841, letter from F. Bishop to Macmillan, July 12, 1961 and the scope of the future National Economic Development Council, cited in Ringe and Rollings, "Responding to Relative Decline," p. 343.

${ }^{3}$ NA, ED 188/155, "Management Education: The State of Play", 8 Jan 1964, page 2.

${ }^{4}$ One might easily read "industrialists" into the phrase "non-academic persons". See NA, ED 46/962, DRO

Thomas memo to Lord Franks, page 1.

${ }^{5}$ For contemporary confirmation, see NA, UGC 7/154, 9 page report on "Management Studies", and NA, ED 188/161, "The London Graduate School of Business Studies Annual Report, 1964-65”, page 11.

${ }^{6}$ For a summary of the experience of the technical colleges in providing the DMS, see NA, BW 91/191, Speech by J.E. Richardson to the British Institute of Management National Conference, Brighton, England, 18 Mar 1965.

${ }^{7}$ NA, ED 188/155, James Platt, "Management Education Today and Tomorrow", speech given to the One Day Conference on New Developments in Management Education organised by the Regional Council for Further Education for the South West. Bristol, May 30, 1962, page 4.

${ }^{8}$ NA, ED 231/2, Second Report of the UKACEM, page 2.

${ }^{9}$ Modern Records Centre, University of Warwick (hereafter MRC), MSS.200/F/4/24/47 \& /48. For some examples, see issues from March 1960 (page 75) and December 1961 (pages 25-6).

${ }^{10}$ MRC, MSS.200/F/1/1/118, Minutes of a Special Meeting Held at 86 Strand, Apr 24, 1963, page 2.

${ }^{11}$ NA, FG 2/120, "What the N.E.D.C. Wants of a Business School", Oct 2, 1963, page 2.

${ }^{12}$ NA, FG 2/120, Mildred Wheatcroft report on "Visit to Business Schools in the United States, 3-13 September 1963 ", page 6 .

${ }^{13}$ NA, ED 188/155, "Management Studies", undated but probably Nov 1962, page 1-2.

${ }^{14}$ NA, ED 188/161, Annual Report for the London Graduate School of Business Studies, page 10.

${ }^{15}$ NA, UGC 7/156, Parnis (UGC) to Church (Min Public Buildings \& Works), Mar 9, 1965.

${ }^{16}$ NA, ED 188/162, Thompson (UGC) to Carswell (DES), Aug 8, 1966, pages 2-3.

${ }^{17}$ NA, UGC 7/157, Thompson (UGC) to Barnes (LBS), Feb 23, 1967.

${ }^{18}$ NA, ED 188/155, "Management Education: The State of Play", Jan 8, 1964, page 1.

${ }^{19}$ MRC, MSS.200/F/3/D3/10/42, Kipping to Marsh, Jun 10, 1963.

${ }^{20}$ Emphasis added. MRC, MSS.200/1/1/F/118, FBI Education Committee minutes, Jan 16, 1964, page 3.

${ }^{21}$ Both quotations from NA, ED 188/161, "London Graduate School of Business Studies: Length of Courses", Oct 1, 1965, pages 5-6.

${ }^{22}$ MRC, MSS.200/F/3/D3/10/42, Sir Archibald Forbes, undated but late summer or early fall, 1963, undated draft on the public responsibilities of management.

${ }^{23}$ NA, ED 188/155, Platt, "Management Education Today and Tomorrow," speech given by JW Platt at the One Day Conference on New Developments in Management Education Organized by the Regional Council for Further Education for the South West, held at Bristol on May 30, 1962, page 4. 